\title{
The Influence of Sitting Work Position and Sitting Time for The Risk of Hemorrhoid in Female Production Workers at The Hand-Rolled Cigarette Factory
} Izzatul Abadiyah $^{1}$, Dewi Sumaryani Soemarko ${ }^{2}$, Herqutanto $^{2}$, Suryo Wibowo ${ }^{2}$, Ambar Roestam $^{2}$

${ }^{1}$ Occupational Medicine Specialist Program, Faculty of Medicine, Universitas Indonesia

${ }^{2}$ Department of Community Medicine, Faculty of Medicine, Universitas Indonesia

Correspondence address: Izzatul Abadiyah

E-mail: izzatul.abadiyah@yahoo.com

\begin{abstract}
Abstrak
Latar belakang: Berdasarkan hasil medical check up perusahaan sigaret kretek tangan PT. X pada tahun 2018 didapatkan prevalensi hemorrhoid sebesar 33\%. Beberapa penelitian yang ada telah berusaha menunjukkan adanya hubungan antara faktor individu seperti usia, riwayat keluarga, konstipasi, obesitas, kehamilan, konsumsi serat, dan posisi defekasi pada subyek penelitian di klinik dan rumah sakit. Akan tetapi, informasi mengenai pengaruh posisi kerja duduk dan lama duduk terhadap risiko terjadinya hemorrhoid masih terbatas. Penelitian ini bertujuan untuk membuktikan adanya pengaruh tersebut terhadap peningkatan risiko terjadinya hemorrhoid.
\end{abstract}

Metode: Studi observasional kasus kontrol tidak berpasangan 1:1 dengan subyek berjumlah 300 pekerja wanita. Faktor risiko terkait hemorrhoid didapatkan dari data primer dan sekunder. Kasus adalah pekerja yang terdiagnosa hemorrhoid dan kontrol adalah pekerja yang tidak terdiagnosa hemorrhoid pada saat medical check up tahun 2018. Analisis data dilakukan secara univariat dan bivariat.

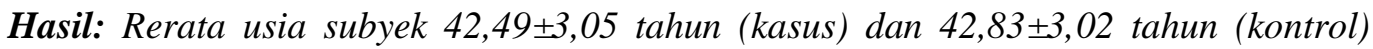
dengan tingkat pendidikan paling banyak adalah SLTP pada kedua kelompok. Analisis bivariat menunjukkan posisi kerja duduk dan lama duduk tidak memiliki hubungan yang bermakna dengan kejadian hemorrhoid. Sedangkan konsumsi kurang buah $(O R=3,84$; IK 95\% 1,87-7,91) dan kurang sayur (OR=2,41; IK 95\% 1,36-4,28) meningkatkan risiko kejadian hemorrhoid dibandingkan konsumsi cukup sayur dan buah.

Kesimpulan: Posisi kerja duduk dan lama duduk tidak berhubungan dengan peningkatan risiko hemorrhoid. Sedangkan konsumsi kurang sayur dan buah meningkatkan risiko terjadinya hemorrhoid.

Kata kunci: posisi kerja duduk, lama duduk, hemorrrhoid, pekerja produksi wanita, pabrik sigaret kretek tangan.

\begin{abstract}
Introduction: According to medical check up results of the hand-rolled cigarette factory PT. $X$ in 2018, a hemorrhoid prevalence of 33\% was found. Several studies have tried to show an association between individual factors such as age, family history, constipation, obesity, pregnancy, fiber consumption, and defecation position in research subjects in clinics and hospitals. Nevertheless, the effects of sitting work position and sitting time on the risk of hemorrhoid is yet to be revealed. This study aims to prove the effect of these factors on the increased risk of hemorrhoids.

Methods: An observational study with a 1:1 unmatched case control design with 300 female workers as subjects. The risk factors related with hemorrhoids were obtained from primary and secondary data. Cases were workers diagnosed with hemorrhoids and
\end{abstract}


IJCOM 2021 July;1(1):3-14

controls were workers who were not diagnosed with hemorrhoids during a medical checkup 2018. Data analysis was performed using univariate and bivariate analysis.

Results: The mean ages of the subjects were $42.49 \pm 3.05$ years old (cases) and $42.83 \pm 3.02$ years old (controls), with most education level was a junior high school in both groups. Bivariate analysis pointed out that sitting work position and sitting time did not have a significant relationship with the incidence of hemorrhoids. Meanwhile, consumption of less fruit $(O R=3.84 ; 95 \% C I$ 1.87-7.91) and less vegetable (OR=2.41;95\%CI 1.36-4.28) increased the risk of hemorrhoid compared to sufficient vegetables and fruit consumption. Conclusion: Sitting work position and sitting time were not associated with an increased risk of hemorrhoids. Meanwhile, consumption of less vegetable and fruit increased the risk of hemorrhoids.

Keywords: Sitting work position, sitting time, hemorrhoid, female production worker, hand-rolled cigarette factory. 


\section{Introduction}

Hemorrhoid are distal displacement and venous distention of the anal cushion which can cause complaints or complications such as pain and bleeding until the surgery is needed. ${ }^{1}$ Problems from physical and psychological discomfort can affect the patient's quality of life. Frequent recurrence rates, incomplete fecal elimination, discomfort including pain even after hemorrhoidectomy requires more effective management in preventing and looking for further risk factors for hemorrhoid events. ${ }^{2,3}$ The prevalence of hemorrhoids is quite high. From the colorectal cancer screening data in the Austrian Wide Health Care Program in four medical institutions in 2012,39\% of the incidence of hemorrhoids was found. ${ }^{2}$ In Korea, hemorrhoid is one of the most common anal diseases in the adult population. The Korea National Health Insurance Corporation reported that hemorrhoidectomy was the second most frequent surgery and had been performed in 220,000 populations in $2012 .{ }^{4}$ Hemorrhoids also occupied the first position of several diseases in the gastrointestinal surgical polyclinic of RSPAD Gatot Soebroto Jakarta in 2012 as many as 789 cases. $^{5}$

Hemorrhoids are hypothesized to result from deterioration of anchoring connective tissue, prolapse of hemorrhoidal tissue, distention of the hemorrhoidal arteriovenous anastomoses or veins dilatation of the hemorrhoidal plexus. ${ }^{1}$ Factors commonly assumed to increase the risk of developing hemorrhoids include inadequate fiber consumption, age, heredity, prolonged sitting position, defecation position, constipation, obesity, and pregnancy. ${ }^{2,4-9}$ Several existing studies have tried to show the relationship between individual factors of the patient with the incidence of hemorrhoids in clinical and hospital study subjects. ${ }^{2,4,5,7-9}$ There have been no studies to date that represent the working population in an industrial environment and more detail examines the relationship between occupational factors including work position, workday sitting time, and work period with hemorrhoid incidence. In addition, evidence regarding these issues has been limited so this study aims to prove the effect of sitting work position and sitting time on the increased risk of hemorrhoids.

\section{Methods}

The research site is a hand-rolled cigarette factory PT. X where $98.9 \%$ of its workers are women with the largest age distribution of 41 to 50 years as much as $60.9 \%$ with a work period of 20 to 35 years. Working days per week are six days with total working hours of 40 hours per week. Female production workers seat in a chair with a hard base, without back and armrests, and with an unadjusted seat height at most of the time during the working hours. The research data was taken from the results of the company's medical check-up in 2018 with a prevalence of hemorrhoids of $33 \%$ obtained from anamnesis and physical examination, both inspection and digital rectal examination. This study used a 1:1 unmatched case control study design. The case group is production workers diagnosed with hemorrhoids during the medical checkup period from March to October 2018 by the researchers themselves and a team of other doctors based on anamnesis and digital rectal examination according to standard examination procedures, while the control group was production workers who were not diagnosed with hemorrhoids by the researchers themselves and a team of other doctors based on anamnesis and digital rectal examination according to standard examination procedures in the same period and population. A total of 150 samples were taken from the cases group and 150 samples from the controls group. The case group was taken randomly from the total number of hemorrhoid cases found as well as the control group after fulfilling the exclusion and inclusion criteria. The study excluded workers with pregnancy and a history of hemorrhoidectomy.

The hemorrhoids was documented and classified according to the international classification recommended by Banov et al. ${ }^{10}$ Potential risk factors related to hemorrhoid events were evaluated both from 
primary data in the form of filling out questionnaires with the inhouse clinic nurses as interviewers, as well as secondary data from personnel and medical check-up data. The study was conducted from August to December 2019. The dependent variable was hemorrhoid and the independent variables were age, educational level, obesity, family history, constipation, defecation position, vegetable consumption, fruit consumption, work period, work position, and sitting time. Subjects were classified into two groups by level of school education (elementary school, junior high school as low level and senior high school, bachelor as high level) and by age group with cut off 45 years old based on the previous studies. ${ }^{3,6}$ Subjects were categorized into two groups according to the definition of obesity recommended by Asian criteria: BMI $\geq 25 \mathrm{~kg} / \mathrm{m}^{2}$ as an obese group and $<25 \mathrm{~kg} / \mathrm{m}^{2}$ as a nonobese group. ${ }^{11}$ The constipation group included those who had more than 15 points for the constipation scoring system. ${ }^{12,13}$ Dietary information was collected using a semi-quantitative Food Frequency Questionnaire. The study defined the sufficient fruit consumption group as those who reported eating fruits 4-6 times a week, once daily, and more than once per day. The study defined the sufficient vegetable consumption group as those who reported eating vegetables once daily and more than once per day. Work unit as mill workers was categorized as continous sitting work position while work unit as scissoring, pack, tag workers were categorized as sitting and standing alternately work position based on the job description. Sitting time was categorized into two groups according to prior study as less than six hours and more than six hours. ${ }^{14}$

The data were collected and the SPSS version 20.0 was used to analyze the data using a univariat and bivariat analysis with a significance level of $p<0.05$. For the variables that were revealed to have significant association, this study estimated odds ratio with $95 \%$ CI associated with the risk of hemorrhoids using bivariate analysis. This study was approved by The Faculty of Medicine Universitas Indonesia-Cipto Mangunkusumo National Hospital (FKUI-
RSCM) Research Ethics Committee (KET882/UN2.F1/ETIK/PPM.00.02/2019) and written informed consent was given by all participants.

\section{Results}

\section{Demographic characteristics of subjects}

Table 1 showed the distribution characteristics of the subjects in the case and control groups. The case group had a younger mean age, a larger mean of body mass index, a longer average of the working period, and more than 6 hours of work sitting time compared to the control group. The most education level in the case group was junior high school graduates at $50.7 \%$, as well as in the control group at $46.7 \%$. Most of the defecation position was sitting in both groups. Most of the subjects in the case and control groups consumed fruit and vegetable 4-6 times/week. The mill and scissor workers are more in the case group when compared to the control, while the pack and tag workers are more in the control group when compared to the case group. The constipation data used the median value because it had an abnormal data distribution. The median value in the case group was higher when compared to the control group.

\section{Risk factors related to hemorrhoid events}

Table 2 showed the relationship and risk of occupational factors in subjects including work position, sitting time, and work period with the incidence of hemorrhoids. Work period as numerical data did not have a significant relationship with the incidence of hemorrhoids using unpaired $\mathrm{T}$ test ( $\mathrm{p}$ value 0.211 ). The work period as categorical data has a significant relationship with the incidence of hemorrhoids ( $p$ value 0.02) with a cut off point of 23 years obtained from the ROC curve. Subjects with a work period of more than 23 years had a 1.71 times greater risk of experiencing hemorrhoids than subjects with a work period of less than 23 years. Work position and sitting time did not have significant relationship with the incidence of hemorrhoids. 
IJCOM 2021 July;1(1):3-14

Table 1. Characteristics distribution of cases and controls

\begin{tabular}{|c|c|c|c|c|c|}
\hline & \multicolumn{2}{|c|}{ Case $(n=150)$} & \multicolumn{2}{|c|}{ Control $(n=150)$} & \multirow{2}{*}{$\begin{array}{c}\text { Total } \\
(n=300)\end{array}$} \\
\hline & $\mathrm{n}(\%)$ & Mean/Median & $\mathrm{n}(\%)$ & Mean/Median & \\
\hline Age (years old) & & $42.49 \pm 3.05^{*}$ & & $42.83 \pm 3.02 *$ & $42.65 \pm 3.03^{*}$ \\
\hline \multicolumn{6}{|l|}{ Education level } \\
\hline Elementary & $44(29.3)$ & & $43(28.7)$ & & $87(29 \%)$ \\
\hline Junior high & $76(50.7)$ & & $70(46.7)$ & & $146(48.7 \%)$ \\
\hline Senior high & $28(18.7)$ & & $35(23.3)$ & & $63(21 \%)$ \\
\hline Bachelor & $2(1.3)$ & & $2(1.3)$ & & $4(1.3 \%)$ \\
\hline Body Mass Index & & $25.49 \pm 4.00 *$ & & $25.21 \pm 4.37 *$ & $25.35 \pm 4.18 *$ \\
\hline \multicolumn{6}{|l|}{ Family history } \\
\hline Yes & $1(0.7)$ & & $1(0.7)$ & & $2(0.7 \%)$ \\
\hline No & $149(99.3)$ & & $149(99.3)$ & & $298(99.3 \%)$ \\
\hline Constipation & & $6.0(0-18) * *$ & & $3.0(0-12) * *$ & $4(0-18) * *$ \\
\hline \multicolumn{6}{|l|}{ Defecation position } \\
\hline Sit & $103(68.7)$ & & $104(69.3)$ & & $207(69 \%)$ \\
\hline Squat & $47(31.3)$ & & $46(30.7)$ & & $93(31 \%)$ \\
\hline \multicolumn{6}{|l|}{ Fruit consumption } \\
\hline Never & $1(0.7)$ & & $1(0.7)$ & & $2(0.7 \%)$ \\
\hline $1-3 x /$ month & $4(2.7)$ & & $1(0.7)$ & & $5(1.7 \%)$ \\
\hline $1-3 x /$ week & $30(20)$ & & $9(6)$ & & $39(13 \%)$ \\
\hline 4-6x/week & $60(40)$ & & $64(42.7)$ & & $124(41.3 \%)$ \\
\hline 1x/day & $47(31.3)$ & & $64(42.7)$ & & $111(37 \%)$ \\
\hline$>1 x /$ day & $8(5.3)$ & & $11(7.2)$ & & $19(6.3 \%)$ \\
\hline \multicolumn{6}{|l|}{ Vegetable } \\
\hline $1-3 x /$ week & $27(18)$ & & $15(10)$ & & $42(14 \%)$ \\
\hline 4-6x/week & $101(67.3)$ & & $91(60.7)$ & & $192(64 \%)$ \\
\hline 1x/day & $15(10)$ & & $30(20)$ & & $45(15 \%)$ \\
\hline$>1 x /$ day & $7(4.7)$ & & $14(9.3)$ & & $21(7 \%)$ \\
\hline Work period (years) & & $23.53 \pm 1.43^{*}$ & & $23.30 \pm 1.68 *$ & $23.41 \pm 1.57 *$ \\
\hline \multicolumn{6}{|l|}{ Work unit } \\
\hline Mill & $99(66)$ & & $97(64.7)$ & & $196(65.3 \%)$ \\
\hline Scissor & $32(21.3)$ & & $28(18.7)$ & & $60(20 \%)$ \\
\hline Pack & $12(8)$ & & $17(11.3)$ & & $29(9.7 \%)$ \\
\hline Tag & $7(4.7)$ & & $8(5.3)$ & & $15(5 \%)$ \\
\hline \multicolumn{6}{|l|}{ Sitting time (hours) } \\
\hline$<6$ & $19(12.7)$ & & $26(17.3)$ & & $45(15 \%)$ \\
\hline$\geq 6$ & $131(87.3)$ & & $124(82.7)$ & & $255(85 \%)$ \\
\hline
\end{tabular}

${ }^{*}$ mean $\pm \mathrm{SD}$

${ }^{\star *}$ median (minimum-maximum value) 
It was found that less vegetable and fruit consumption had a significant relationship with the incidence of hemorrhoid $(\mathrm{p}<0.05)$. Less vegetable consumption has a risk of increasing hemorrhoids by 2.41 times greater when compared to sufficient vegetable consumption. Subjects who consume less fruit will have a risk of hemorrhoids by 3.84 times greater when compared to subjects who consume sufficient fruit. Work period more than 23 years has a risk of increasing hemorrhoids by 1.71 times. The other risk factors haven't shown significant relationship.
It was found that less vegetable and fruit consumption had a significant relationship with the incidence of hemorrhoid $(p<0.05)$. Less vegetable consumption had a risk of increasing hemorrhoids by 2.41 times greater when compared to sufficient vegetable consumption. Subjects who consume less fruit had a risk of hemorrhoids by 3.84 times greater when compared to subjects who consume sufficient fruit. The other risk factors haven't shown significant relationship.

Table 2. Relationship between occupational factors and hemorrhoid

\begin{tabular}{lccccc}
\hline & $\begin{array}{c}\text { Case } \\
\mathrm{n}(\%)\end{array}$ & $\begin{array}{c}\text { Control } \\
\mathrm{n}(\%)\end{array}$ & Total & $\mathrm{p}$ Value & OR (95\%CI) \\
\hline Work period (years) & $87(58 \%)$ & $67(44,7 \%)$ & 154 & $0,02^{\mathrm{cs}}$ & $1,71(1,08-2,70)$ \\
$>23$ & $63(42 \%)$ & $83(55,3 \%)$ & 146 & & \\
$\leq 23$ & & & & & \\
Work Position & $99(66 \%)$ & $97(64,7 \%)$ & 196 & $0,8^{\mathrm{cs}}$ & $1,06(0,65-1,70)$ \\
Continous sitting position & $51(34 \%)$ & $53(35,3 \%)$ & 104 & & \\
$\begin{array}{l}\text { Sitting and standing } \\
\text { alternately }\end{array}$ & & & & & \\
Sitting time & $131(87,3 \%)$ & $124(82,7 \%)$ & 255 & $0,258^{\mathrm{cs}}$ & $1,44(0,76-2,74)$ \\
$\geq 6$ jam & $19(12,7 \%)$ & $26(17,3 \%)$ & 45 & & \\
$<6$ jam & & & & & \\
\hline
\end{tabular}

cs) chi square

fe) fisher exact 
IJCOM 2021 July;1(1):3-14

Table 3. Relationship between individual factors and hemorrhoid

\begin{tabular}{|c|c|c|c|c|c|}
\hline & $\begin{array}{l}\text { Case } \\
\mathrm{n}(\%)\end{array}$ & $\begin{array}{c}\text { Control } \\
\mathrm{n}(\%)\end{array}$ & Total & $\mathrm{p}$ Value & OR $(95 \% \mathrm{CI})$ \\
\hline \multicolumn{6}{|c|}{ Age (years) } \\
\hline$\geq 45$ & $42(28 \%)$ & $37(24,7 \%)$ & 79 & $0,512^{\mathrm{cs}}$ & $1,18(0,71-1,99)$ \\
\hline$<45$ & $108(72 \%)$ & $113(75,3 \%)$ & 221 & & \\
\hline \multicolumn{6}{|c|}{ Education level } \\
\hline Low & $120(80 \%)$ & $113(75,3 \%)$ & 64 & $0,332^{\mathrm{cs}}$ & $1,31(0,76-2,26)$ \\
\hline High & $30(20 \%)$ & $37(24,7 \%)$ & 236 & & \\
\hline \multicolumn{6}{|l|}{ Obesity } \\
\hline Yes & $80(53,3 \%)$ & $75(50 \%)$ & 155 & $0,563^{\mathrm{cs}}$ & $1,14(0,72-1,79)$ \\
\hline No & $70(46,7 \%)$ & $75(50 \%)$ & 145 & & \\
\hline \multicolumn{6}{|c|}{ Family history } \\
\hline Yes & 1 & 1 & 2 & $1,000^{\mathrm{fe}}$ & $1,00(0,06-16,13)$ \\
\hline No & 149 & 149 & 298 & & \\
\hline \multicolumn{6}{|c|}{ Constipation } \\
\hline Yes & $5(3,3 \%)$ & 0 & 5 & $0,06^{\mathrm{fe}}$ & N/A \\
\hline No & $145(96,7 \%)$ & $150(100 \%)$ & 295 & & \\
\hline \multicolumn{6}{|c|}{ Defecation position } \\
\hline Sit & $103(68,7 \%)$ & $104(69,3 \%)$ & 207 & $0,90^{\mathrm{cs}}$ & $0,97(0,59-1,58)$ \\
\hline Squat & $47(31,3 \%)$ & $46(30,7 \%)$ & 93 & & \\
\hline \multicolumn{6}{|c|}{ Vegetable consumption } \\
\hline Less & $128(85,3 \%)$ & $106(70,7 \%)$ & 234 & $0,002^{\mathrm{cs}}$ & $2,41(1,36-4,28)$ \\
\hline Sufficient & $22(14,7 \%)$ & $44(29,3 \%)$ & 66 & & \\
\hline \multicolumn{6}{|c|}{ Fruit consumption } \\
\hline Less & $35(23,3 \%)$ & $11(7,3 \%)$ & 46 & $<0,001^{\mathrm{cs}}$ & $3,84(1,87-7,91)$ \\
\hline Sufficient & $115(76,7 \%)$ & $139(92,7 \%)$ & 254 & & \\
\hline
\end{tabular}

cs) chi square; fe) fisher exact 


\section{Discussions}

Recent research among both Western and Asian working adults found that occupational sitting time contributed greatly toward daily sitting time. According to previous reports, a continous sitting position will cause relaxation/weakening of the supporting connective tissue, smooth muscles, and blood vessels in the anal cushion, which if this situation occurs for a long time will have an impact on the downward sliding of the anal pillow. In a continous sitting position there will also be blood stasis in the venular arteriolar anastomosis which can inhibit and cause congestion and dilation of the hemorrhoidal sinusoids. ${ }^{15-18}$ Unfortunately, continuous sitting work position in this study had no significant relationship with the incidence of hemorrhoids. The results of a prior case control study on 2813 respondents in eleven centers in the United States and Puerto Rico showed that sedentary behavior defined as a daily sitting time with an average value of $370 \pm 198$ minutes showed a significant relationship with the incidence of hemorrhoids with $\mathrm{p}<0.001$. However, when matched with age and gender, the prolonged sitting position with the highest quartile average sitting value of 656 minutes/day showed a reduced risk of hemorrhoids. ${ }^{14}$ The female production workers at the handrolled cigarette factory PT. X as subjects of this study had a stretching program at 09.00 am every day for 8 minutes since 2010 that could play a role in helping blood circulation to be better. All workers are required to stand up and follow the movements according to the instructions, led by a supervisor and a team of healthy ambassadors in each production unit. Related to this, further research can be done regarding the effectiveness of stretching concerning various risks of health problems. Furthermore, it was found that hemorrhoids could increase the risk of coronary heart disease (CHD) by 1.27 times greater after adjusting for potential confounding factors in a cohort study in 2017 on 33,034 hemorrhoid patients and 132,136 non hemorrhoid patients with a follow-up period of 12 years. This study described several theories that might explain the increased risk of CHD in hemorrhoid patients related to increased abdominal circumference and pressure, obesity, and physical inactivity that contribute to blood stasis in pelvis where all of these factors were correlated with the atherosclerosis process which played an important role with the occurrence of CHD. ${ }^{19}$ A similar analogy study was seen in the same retrospective cohort study from The Taiwanese Longitudinal Health Insurance Database 2000 (LHID2000) involving 37,992 hemorrhoid patients and 37,992 non-hemorrhoid patients without comorbidity who showed evidence of an increased risk of Peripheral Artery Occlusive Disease (PAOD) by 1.62 times. Matrix metalloproteinases (MMPs) play an important role in the pathogenesis of PAOD which has also been reported to be associated with hemorrhoid events. Several factors may explain the increased risk of PAOD among hemorrhoid patients. First, the role of inflammation which is believed to be the main trigger for acute atherosclerosis. Second, patients with hemorrhoids tend to have a sedentary lifestyle and obesity that strongly associated with the development of PAOD. ${ }^{20}$ This also needs to be a concern for stakeholders regarding how to prevent and control the risks that exist not only for the incidence of hemorrhoids itself but also regarding the prognosis of this disease on other health problems.

The work period over 23 years had a significant relationship to the incidence of hemorrhoids with a risk of 1.71 times when compared with subjects with a work period fewer than 23 years (p 0.01; OR $1.7195 \%$ CI 1.08-2.70). The work period is linear with the increasing age of workers, but age in this study did not have a significant relationship with the incidence of hemorrhoids. In the seven steps of establishing an occupational diagnosis from IOMA (The Indonesian Occupational Medicine Association), the work period will be affected as the dose of exposure adequacy (step four) if potential hazard factors in the workplace are identified. However, the prolonged sitting work position here is not a potential hazard for workers to hemorrhoid events so that the 
work period does not have significant implications for the company.

Consumption of less vegetable and fruit showed a significant association with the increased risk of hemorrhoids compared to consumption of sufficient vegetable and fruit. The results of this study are consistent with previous research at eleven centers in the United States and Puerto Rico which showed that total fiber consumption was associated with a reduced risk of hemorrhoid events with a p-value of $0.03 .{ }^{14}$ Fiber will help increase the volume of stool, soften the consistency of stool by increasing the absorption of water in the digestive tract, increasing intestinal motility, and stimulating nerves in the rectum to stimulate defecation. Several trials have found also that dietary fiber is an effective treatment for symptomatic hemorrhoids. ${ }^{21}$

The number of respondents in the case group who had a total constipation score $>15$ were only 5 respondents, while in the control group there were no respondents who had a total constipation score above 15 so OR of this data could not be assessed further. The results of previous studies, namely a study on 2813 participants from eleven centers in the United States and Puerto Rico, showed an association between constipation and an increased prevalence of hemorrhoids with OR 1.43 (95\% CI 1.111.86). Diagnosis of constipation used in this study was based on Rome I criteria which were enforced by answering two or more of the questions: 1) frequency of straining when defecating for $25 \%$ of the time or more, 2) feeling dissatisfied with defecation at $25 \%$ of the time or more, 3 ) consistency hard stools $25 \%$ of the time or more, and 4 ) reported less than three frequency of defecation in one week. This study did not use this diagnostic criterion because it was difficult to describe $25 \%$ of the time and there was no more detailed score for each question, it was only obtained through yes or no answers from respondents. There was also no question on this diagnostic criterion regarding the length of time taken at defecation, which greatly influences the occurrence of hemorrhoids. ${ }^{16}$ A study involving 976 patients who participated in The Nationwide Healthcare Program for
Colorectal Cancer in Austria showed a significant association between constipation and the incidence of hemorrhoids measured using the Constipation Scoring Systems questionnaire. The median value in that study was quite low, namely 3 points in patients with hemorrhoids and 2.5 points in patients without hemorrhoids with a minimum value of 0 and a maximum value of $19 .^{2,21}$ It seems that the minimum and maximum value limits are also seen to be the same in this research. Although it does not have a significant relationship with the incidence of hemorrhoids as categorical data, it can be seen that subjects who have a total score of $\geq 15$ constipation are all in the case group and the relationship of constipation as numerical data shows a significant $\mathrm{p}$-value $(\mathrm{p}<0.001)$.

Study subjects over 45 years of age did not have a significant relationship with the incidence of hemorrhoids ( $p$-value 0.512 ). These results are inconsistent with existing studies of hemorrhoid patients ranging in age from 16 to 80 years at the Park Clinic Berlin who concluded that those over 46 years of age have a high risk of hemorrhoid events (p 0.006; OR 3.824, 95\% CI 1.468- 9.961). In the 2019 case control study of 202 subjects at the Surgery Clinic Universiti Kebangsaan Malaysia Medical Center (UKMMC), there was a significant relationship between age and the incidence of hemorrhoids (p 0.02; OR 2.268, 95\% CI 1.107-4.630). ${ }^{8}$ In this study, the relationship could not be proven may be because the narrow age range of the subjects, namely 36 to 53 years. Age over 45 years seems to have an impact on the decrease in collagen quality, the disintegration of treitz muscle and conjoined longitudinal muscles, and degeneration of anal sphincter muscle tissue becomes thinner and atonic. The highest prevalence of hemorrhoids at age 45 years was also seen in a cohort study conducted on 33,034 subjects from the Longitudinal Health Insurance Database 2000 (LHID2000) in Taiwan. ${ }^{17}$ The highest prevalence of hemorrhoids in the 40 to 59 year age group was seen in the study of 17,228 subjects the 4th Korean National Health and Nutrition Examination Survey (KNHANES). ${ }^{4}$ However, hemorrhoids were 
common in subjects under 45 years of age as well as subjects in this study.

Education level as well as family history is not a factor that influences research, which may be because the fact about hemorrhoids insight and healthy lifestyle habits, including consuming enough fiber, is not currently obtained from formal education alone. Health-related information can be accessed from various sources. The subjects may not have insufficient information from the subjects regarding genetic information. It can be seen that there are only two subjects who claim to have a family history of hemorrhoids. This could be because of the subject's ignorance or undiagnosed hemorrhoids in family members who actually had complaints of illness but did not seek treatment.

Obesity did not have a relationship with the incidence of hemorrhoids in this study which may be due to changes in BMI of subjects from time to time that could not be studied using a case control study design. This relationship can be analyzed properly using a prospective cohort study. This result is inconsistent with previous research on 976 respondents who participated in The National Wide Health Program for Colorectal Cancer Screening, which showed that BMI had a significant relationship with the incidence of hemorrhoids with a p-value of 0.02 in multivariate analysis with $\mathrm{OR}$ 1.035 (95\% CI 1.004- 1.067). Even after controlling for other risk factors, it was found that an increase in BMI would increase the risk of hemorrhoids by $3.5 \% .^{2}$ The association between obesity and an increased risk of hemorrhoid events was also seen in a study of 17,228 subjects who were members of the KNHANES with an OR value of 1.13 (95\% CI 1.01-1.26). ${ }^{4}$ Increased intra-abdominal pressure in obesity with high body fat and visceral fat is thought to provoke venous congestion of the distal rectum and chronic inflammatory mechanisms associated with increased release of inflammatory cytokines and acute phase proteins (C-reactive protein) which steadily activates the innate immune system and affects metabolic homeostasis. ${ }^{4,23}$ The association of obesity to hemorrhoid events may be seen in subjects with abdominal obesity because of the pathophysiology associated with increased intra-abdominal pressure so that it can be used as an input for additional measurements of abdominal circumference in the next study. An analogy study of obesity and inflammatory factors with the incidence of hemorrhoids was seen in a cohort study of subjects in LHID2000 Taiwan that showed an increased risk of peripheral artery occlusion disease in hemorrhoid sufferers. ${ }^{20}$

The sitting position during defecation can result in a greater effort to empty the rectum which increase intraabdominal pressure which if it continues, will cause a decrease in venous return towards superior rectal venous and medial rectal venous. This allows for the congestion and dilatation of the sinusoids of the anal cushion. In contrast to the squatting position during defecation where the iliocaecal valvula which is located between the small intestine and the caecum, can close completely so that the pressure in the colon is sufficient to expel feces. ${ }^{5}$ Study in Japan using a urodynamic computer (Urovision, Lifetech Inc, Houston, TX), anorectal videomanometry showed that the greater hip flexion was achieved by squatting position during defecation where with an anorectal angle of $126^{\circ}$, the rectoanal canal became straighter so that the pushing process can be easier and less strain will be required for defecation than sitting position with an anorectal angle of $100^{\circ} .{ }^{24}$ However, in this study, the position at defecation had no significant relationship with the incidence of hemorrhoids either which was possible because the subjects still alternated sitting or squatting position during defecation depending on the type of toilet provided where this answer option was not included in the research questionnaire.

The present study has several strengths. It was conducted in representative samples selected by the probability random sampling method, considered a wide range of probable risk factors. It also examined the anorectal region directly not only questioning symptoms correlated with hemorrhoids. The limitations include the measurement of sitting time based on interviews through 
filling out questionnaires and not using objective measuring instruments that allow for information bias and recall bias. The diagnosis of gold standard hemorrhoids using anoscopy was not performed in this study. However, this limitation has been into consideration.

\section{Conclusion}

This study revealed that sitting work position and sitting time were not associated with an increased risk of hemorrhoids among female production workers at the hand-rolled cigarette factory. In addition, consumption of less vegetable and fruit increased the risk of hemorrhoids. Further research using an objective parameter for calculating sitting time and having a cohort study, as well as bigger samples to build up a causal relationship level of evidence would give more comprehensive results.

\section{Acknowledgements}

We would like to thank to the employees of hand-rolled cigarette factory for their willingness as subjects and nurses at inhouse clinic who was an interviewers during data collection.

\section{References}

1. Ganz RA.The evaluation and treatment of hemorrhoids: a guide for the gastroenterologist. Clinical gastroenterology and hepatology: the official practice journal of the American Gastroenterology-cal Association. 2013;11: p. 603-593. doi:10.1016/j.cgh.2012.12.020.

2. Riss S, Weiser FA, Schwameis K, Riss T, Mittlbock M, Steiner G, et al. The prevalance of hemorrhoids in adults. Int $\mathbf{J}$ Colorectal Dis. 2012;27: p. 220-215. doi:10.1007/s00384-011-1316-3.

3. Giordano P, Gravante G, Sorge R, Ovens L, Nastro P. Longterm outcomes of stapled hemorrhoidopexyvs conventional hemorrhoidectomy: a meta-analysis of randomized controlled trials. Arch Surg 2009;144: p. 272-266.

4. Lee JH, Kim HE, Kang JH, Shin JY, Song YM. Factors associated with hemorrhoids in Korea adults: The 4th Korean National Health and Nutrition Examination Survey. Korean J Fam Med 2014;35: p. 236-227. doi:10.4082/kjfm.2014.35.5.227.

5. Pambudi AR, Soehendro B, Widasari L. Hubungan antara posisi defekasi terhadap kejadian hemorrhoid di poli bedah anoskopi RSPAD Gatot Soebroto periode Maret dan April 2013. Cendana medical journal. 2016;6: hal 98.

6. Everhart JE, Ruhl CE. Burden of digestive diseases in the United States part II: lower gastrointestinal diseases. Gastroenterology. 2009;136: p. 754-741. doi:10.1053/j.gastro.2009.01.015

7. Pigot F, Siproudhis L, Allaert FA. Risk factors associated with hemorrhoidal symptoms in specialized consultation. Gastroenterol Clin Biol. 2005;29: p. 1270-1274

8. Karim J, Abdullah AAA, Zolkiflie AK, Roslan NS, Kumar S, Shiong KC. A case control study on physical activity and body mass index associated with hemorrhoids. Jurnal Ners 2019; 14(3si): p. 121-125.

9. Tevin LR, Arifin F, Pramono A. The correlation between family history, constipation, defecation position, and defecation time with hemorrhoid among patients in general surgery outpatient clinic DR. Mohamad Soewandhie regional public hospital Surabaya. Journal of Widya Medika. 2019; 1(1): p. 26-32.

10.Banov L, Knoepp LF, Erdman LH, et al. Management of hemorrhoidal disease. J S C Med Assoc 1985;81: p. 398-401.

11.James W, Chunming C, Inoue S. Appropiate Asian Body Mass Indices?. Obesity reviews 2002;3: p. 139.

12.Mccrea GL, Miaskowski C, Stotts NA, Macera L, Hart SA, Varma MG. Review article: self-report measures to evaluate constipation. Aliment Pharmacol Ther 2008. 27, 638-648.

13. Shruti Sharma, Brij BA. Scoring Systems in Evaluation of Constipation and Obstructed Defecation Syndrome (ODS). JIMSA January-March 2012 Vol. 25 No. 1. 
14.Peery AF, Sandler RS, Galanko JA, Bresalier RS, Figueiredo JC, Ahnen DJ, et al. Risk factors for hemorrhoids on screening colonoscopy. PLoS ONE 2015;9-1. doi:10.1371/journal.pone.0139100.

15.Gardner IH, Sidd RV, Tsikitis VL. Benign anorectal disease: hemorrhoids, fissures, and fistulas. Annals of Gastroenterology 2020;33: p. 9-18.

16.Sun Z, Migaly J. Review of Hemorrhoid Disease: Presentation and Management. Clin Colon Rectal Surg 2016;29:22-29.

17.Chang SS, Sung FC, Lin CL, Hu WS. Association between hemorrhoid and risk of coronary heart disease. Medicine 2017; 96:31.

18. Yamana T. Japanese practice guidelines for anal disorders. J Anus Rectum Colon 2017; 1(3): 89-99.

19. Chang SS, Sung FC, Lin CL, Hu WS. Association between hemorrhoid and risk of coronary heart disease. Medicine 2017; 96:31.

20.Hu WS, Lin CL. Hemorrhoid is associated with increased risk of peripheral artery occlusive disease: A nationwide cohort study. Journal of epidemiology 2017; 27: 574-577.

21.Alonso CP, Mills E, Heels AD, Lopez YM, Zhou Q, Johanson JF et al. Fiber for the treatment of hemorrhoids complication: a systematic review and meta-analysis. The American Journal of gastroenterology. 2006; 101(1): p. 181-8.

22.Riss S, Weiser FA, Schwameis K, Mittlbock M, Stift A. Haemorrhoids, constipation and faecal incontinence: is there any relationship?. Colorectal disease: the official journal of the Association of Coloproctology of Great Britain and Ireland. 2011; 13(8): 227-33.

23.Lumeng CN, Saltiel AR. Inflammatory links between obesity and metabolic disease. J Clin Invest 2011;121:2111-7.

24.Sakakibara R, Tsunoyama K, Hosoi H, Takahashi O, Sugiyama M, Kishi M et al. Influence of body position on defecation in humans. LUTS. 2010;2: p 16-21. 